\title{
WestVirginiaUniversity
}

THE RESEARCH REPOSITORY @ WVU

West Virginia Agricultural and Forestry Experiment

Davis College of Agriculture, Natural Resources

Station Bulletins

And Design

$1-1-1959$

\section{Possibilities for reducing apple packing house costs}

Homer C. Evans

R.S. Marsh

Follow this and additional works at: https://researchrepository.wvu.edu/ wv_agricultural_and_forestry_experiment_station_bulletins

\section{Digital Commons Citation}

Evans, Homer C. and Marsh, R. S., "Possibilities for reducing apple packing house costs" (1959). West Virginia Agricultural and Forestry Experiment Station Bulletins. 436.

https://researchrepository.wvu.edu/wv_agricultural_and_forestry_experiment_station_bulletins/413 @ WVU. It has been accepted for inclusion in West Virginia Agricultural and Forestry Experiment Station Bulletins by an authorized administrator of The Research Repository@WVU. For more information, please contact ian.harmon@mail.wvu.edu. 
-

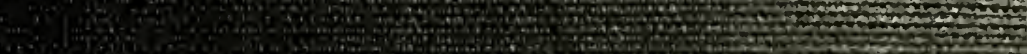
6.

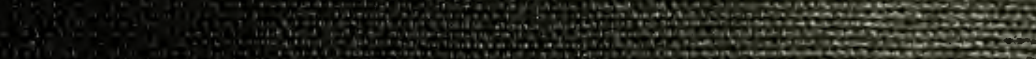

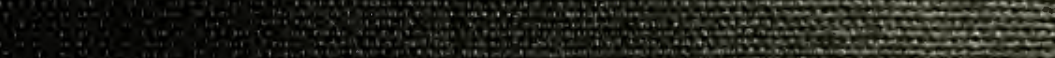

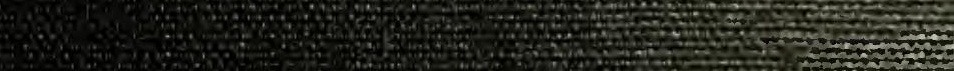
4.

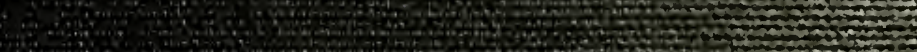
S. 35 .

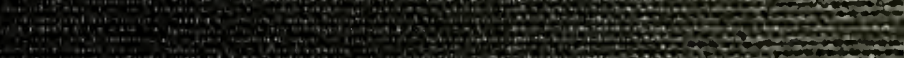

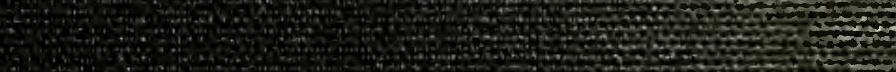
- 1 in

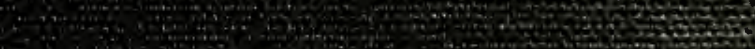

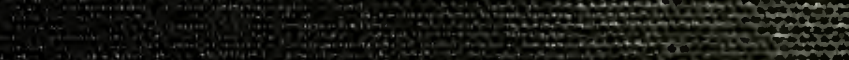

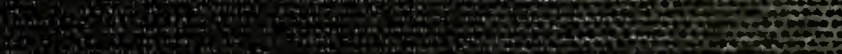

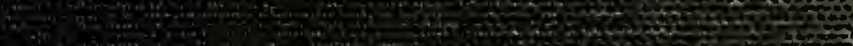
(19.

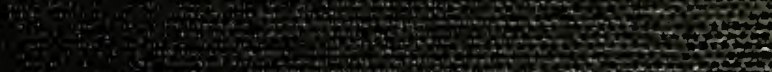

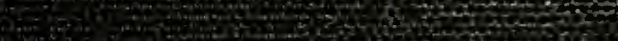

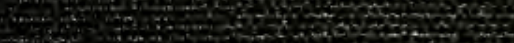
tw. (2) a

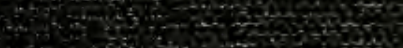

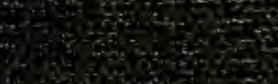

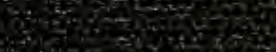

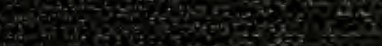

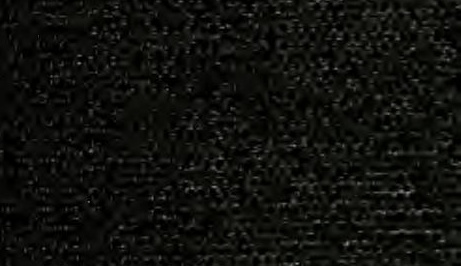
(3) (1)

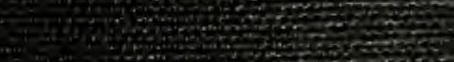

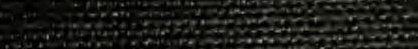

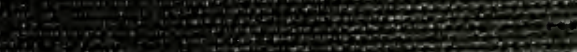

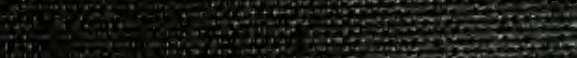

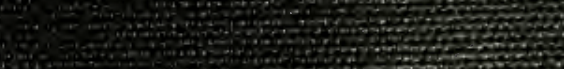

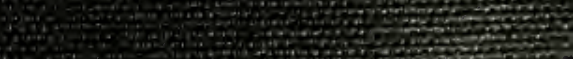
4.

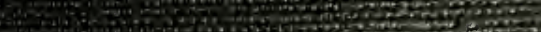
W i 

Possibilities for Reducing Apple Packing House Costs

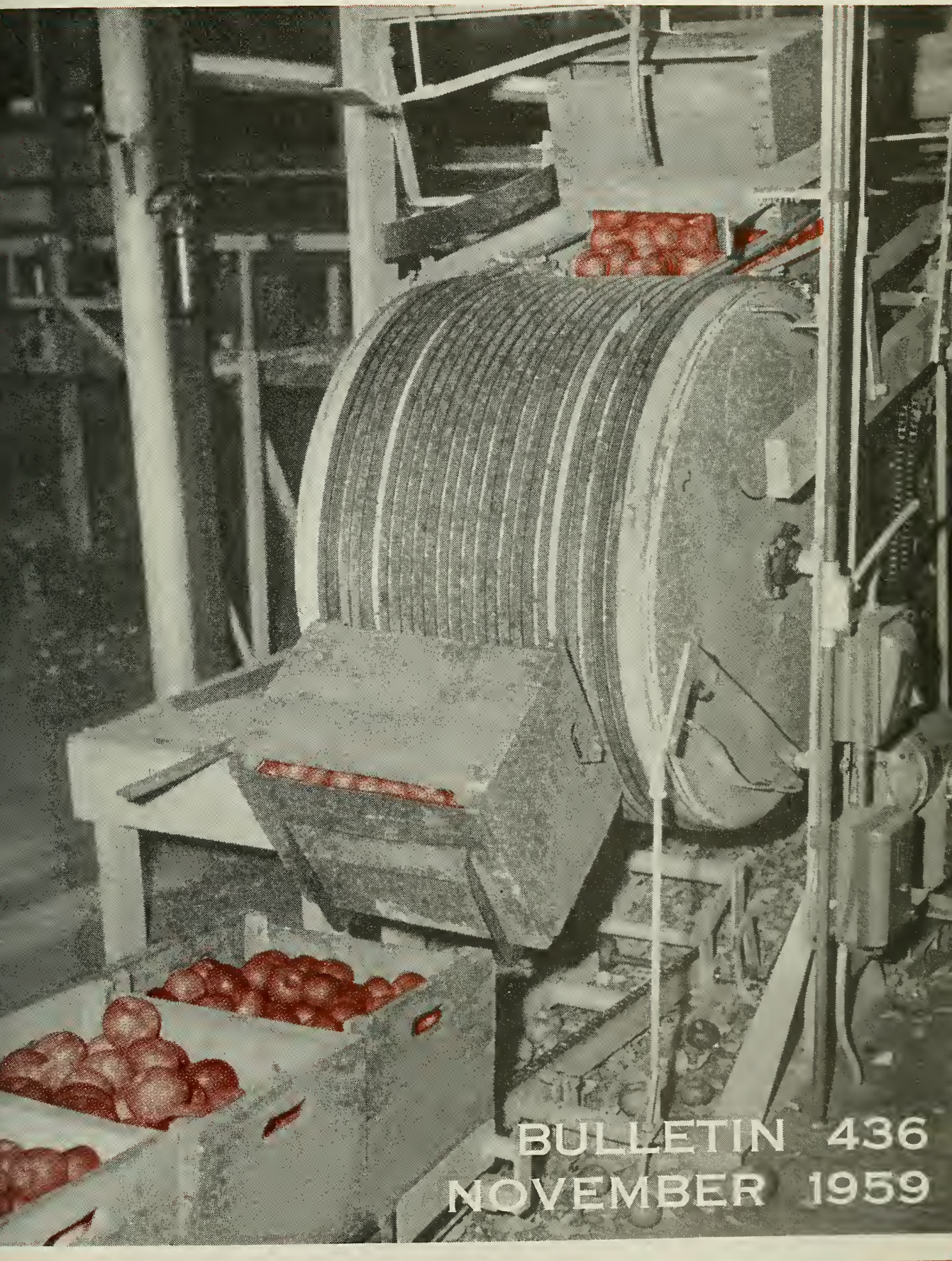


Digitized by the Internet Archive in 2010 with funding from

Lyrasis Members and Sloan Foundation 


\section{Preface}

THIS is the third of a series of reports covering work done on handling methods and costs of packing apples in the Appalachian Area. The over-all project has the following objectives: to discover ways of reducing costs of handling, packing, and storing apples under conditions prevailing in the Appalachian Area; and to determine the extent of mechanical injury to apples caused by different handling and packing equipment and methods. The first report (Costs and Mechanical Injury in Handling and Packing Apples, West Virginia University Agricultural Experiment Station Bulletin 416, Evans and Marsh, 1958) deali with the costs of packing and handling apples and the degree of mechanical injury for the 1956 crop. A second report (Costs of Marketing Appalachian Apples, USDA, AMS, Marketing Research Report No. 300, Powell and Hanes, 1959) was concerned with the average packing and marketing costs and returns within a sample of large apple packers in the Appalachian Area for the 1957 crop. This third report is concerned with the possibilities for further reducing costs in two of the more efficient packing houses included in the first two studies. Ensuing reports will deal with an evaluation of the relative efficiency of different machines and work methods in reducing costs.

The current study was carried out jointly by the West Virginia University Agricultural Experiment Station and the Agricultural Marketing Service (AMS), United States Department of Agriculture (USDA). It is a part of Northeast Regional Project NEM-19, "Handling Methods and Costs in Storing and Packing Apples." 


\section{ACKNOWLEDGMENT}

The authors appreciate the cooperation of the operators of the Chert Mountain and Consolidated Orchards. They were most. helpful in making data available and in permitting the researchers to study their operations.

Mr. Robert L. Jack collected the data and helped in its tabulation.

\section{THE AUTHORS}

Authors of Possibilities for Reducing Apple Packing House Costs are Homer C. Evans and Ray S. Marsh. Homer C. Evans is Professor of Agricultural Economics in the College of Agriculture, Forestry, and Home Economics, and Agricultural Economist in the Agricultural Experiment Station. Ray S. Marsh is Professor and Head of Horticulture in the College of Agriculture, Forestry, and Home Economics, and Horticulturist in the Agricultural Experiment Station.

WEST Virginta UNIVERSITY

Agricultural Experiment Station

College of Agriculture, Forestry, and Home Economics

A. H. Vanlandingham, Director

MORGANTOWN 


\section{Possibilities For Reducing Apple Packing House Costs}

HOMER C. EVANS and RAY S. MARSH

\section{Introduction}

THE following is a summary statement taken from the first of this series of reports dealing with apple packing and handling costs:

"The most significant findings of this study are: the wide variation in packing and handling costs and mechanical injury to apples among operators, and tîe lack of any relationship between packing costs and mechanical injury: This suggests that there is an opportunity for most operators to reduce both costs and mechanical injury. If all operators could become as efficient as the lowest-cost operators, the costs of packing and handling apples in the Anpalaclian Area would be reduced considerably. No doubt, even the present low-cost operators could further improve their methods. This would mean even more savings in packing and handling costs."1

As a follow-up of these findings, two of the more efficient packing houses originally studied were selected for study during the 1958-59 packing season. ${ }^{2}$ The purpose of the 1958-59 study was to determine if existing low-cost operators could further reduce packing house costs.

\section{Effects of Automatic Box Filler on Costs}

In one of the packing houses selected for study, the table culls formerly had been hand-packed in field crates from reverse flow belts. ${ }^{3}$ An automatic box filler was installed during the 1958-59 packing season (Picture 1). With the aid of the automatic box filler, it was found that one man could supply the crates and stack the filled crates coming from the machine at the rate of three crates per minute. The 0.33 man-minutes per crate required in conjunction with the automatic box filler, compares with 0.78 man-minutes per crate required without the aid of the automatic box filler in the same packing house. ${ }^{*}$ Assuming that it costs annually 20 per cent of the original cost $(\$ 1,000)$ to own and operate

\footnotetext{
${ }^{2}$ Evans, Homer C. and Marsh, Ray S., Costs and Mechanical Injury in Handling and Packing Apples, West Virginia University Agricultural Experiment Station Bulletin 416 , June 1958, pp. 24-25.

${ }^{2}$ For a description of the procedures used in this study see Evans, ibid., p. 5, and Powell, Jules V. and Hanes, John K., Cost of Harketing Appalachian Apples, USDA, AMS, MarketIng Research Report No. 300, February 1959, p 7 .

${ }^{3} \mathrm{Box}$, crate, and bushel are used synonymously.

${ }^{4}$ Powell, ibid. p. 21.
} 


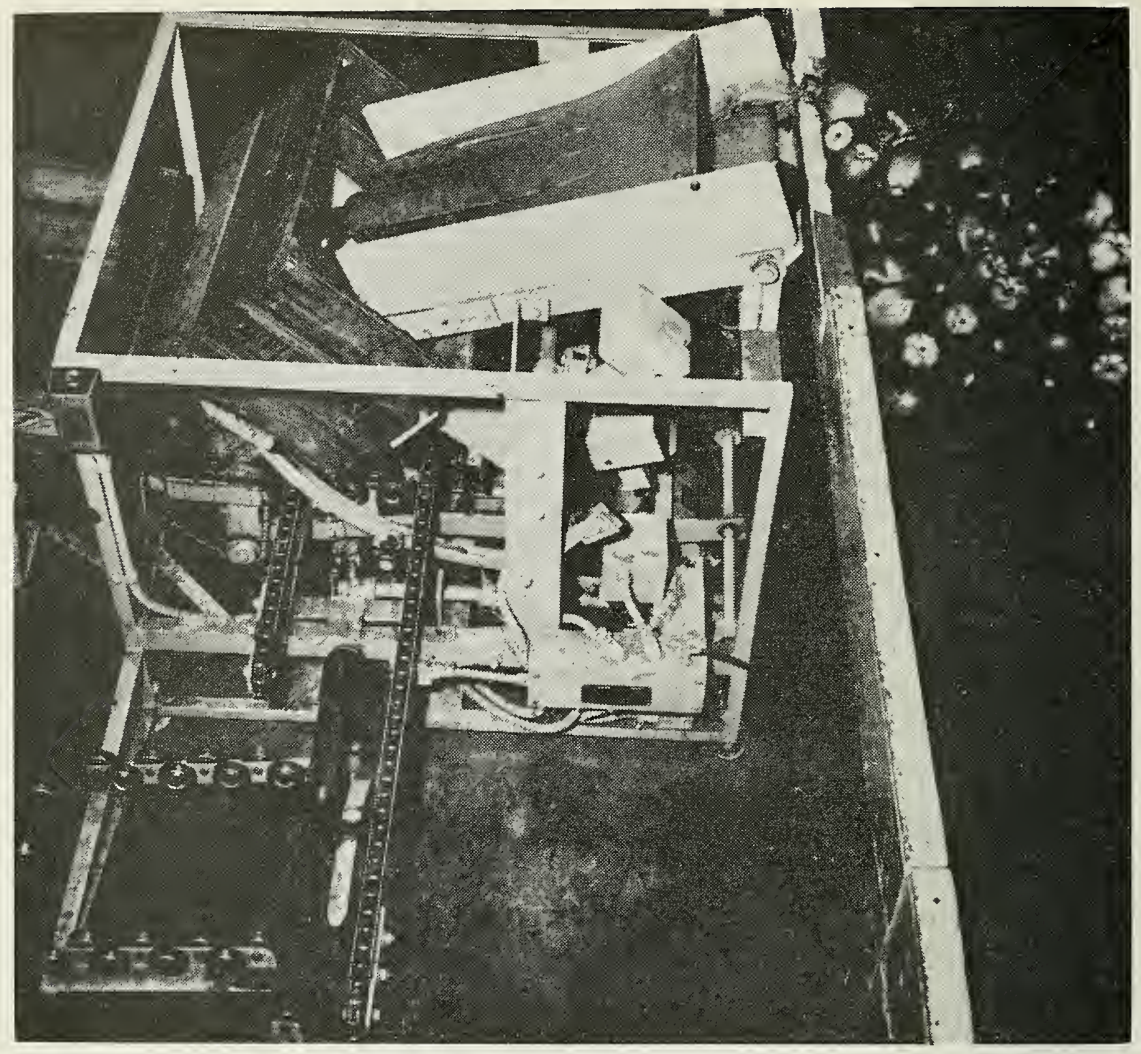

PICTURE 1. Automatic box filler.

(exclusive of operating labor costs) the automatic box filler, the annual cost would be $\$ 200 .^{5}$ With a wage rate of $\$ 1.00$ per hour, a packing operation would need a volume of 28,000 crates per year for the automatic box filler before any net saving would be made by its installation. However, some of the higher-cost operators were requiring 2.3 manminutes per crate ${ }^{6}$ to fill by hand. Under the same set of assumptions these operators could afford to install the automatic box filler with a volume of only 6,500 bushels per year. A low-cost operator would save $\$ 7.20$ per thousand crates for all over 28,000 crates filled by the machine. A high-cost operator should be able to save even more per thousand

${ }^{5}$ The 20 per cent is arbitrary; it seems to be reasonable. It would be broken down as follows: 10 per cent for denreciation, 5 per cent for repairs, power, and upkeep; 3 per cent interest on the original investment, which is equal to slightly over 5 per cent of the average undepreciated value over the life of the equipment; and 2 per cent for taxes, and insurance.

${ }^{\circ}$ Powell, ibid. p. 21. 
crates. It would be to the advantage of a low-cost operator with volumes of less than 28,000 crates to use the hand method of filling field crates.

It was the opinion of the researchers and packing house operators that the usual manual method of rolling table culls into field crates rould cause as much or more bruising than the automatic box filler. Comparable bruise data were not taken for both methods.

\section{Effects of Remodeling on Costs}

In a second packing house, the handling and packing operations were changed at a cost of $\$ 35,000$ (Picture 2). Automation was introduced in handling, destacking, and dumping operations. Also, sizing and packing operations were made more flexible. Table 1 gives the effects of the changes introduced on labor requirements in this packing house. Average labor requirements were reduced 43 per cent per tray package by the changes introduced.

Table 2 gives a comparison of mechanical injury to apples both before and after remodeling. Variance analysis of the data in Table? reveals that less mechanical injury occurred after remodeling than before.

Since the $\$ 35,000$ is only the additional cash outlay for the remodeling (total cost of remodeling would be $\$ 35,000$ plus trade-in value of

Table 1. Labor Requirements for Handling and Tray Packing

Apples Before and After Remodeling

\begin{tabular}{|c|c|c|}
\hline \multirow[b]{2}{*}{ LABOR ITEMS } & \multicolumn{2}{|c|}{ Man-Minutes Per Box } \\
\hline & $\begin{array}{c}\text { BEFORE CHANGE } \\
1956-1957\end{array}$ & $\begin{array}{c}\text { After ChaNGE } \\
\text { 1958-1959 }\end{array}$ \\
\hline General Labor* ..... & 11.53 & 6.39 \\
\hline Packing (by hand) & 5.07 & 3.67 \\
\hline Lidding & 1.67 & .38 \\
\hline Total & 18.27 & 10.44 \\
\hline
\end{tabular}

* General labor includes the following operations: dumping, grading, packing the table culls, stamping, weighing, tallying, stacking empty boxes, stacking packed containers, supervising and miscellaneous.

Table 2. A Comparison of Meghanical Injury to Golden Delicious Apples Before and After Remodeling Packing Equipment

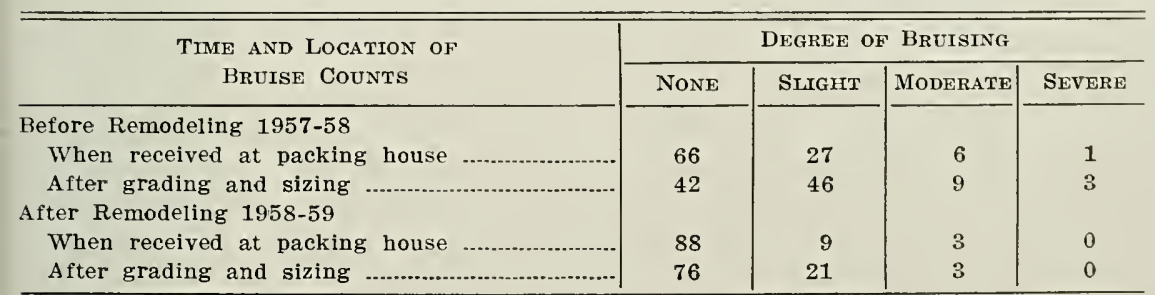




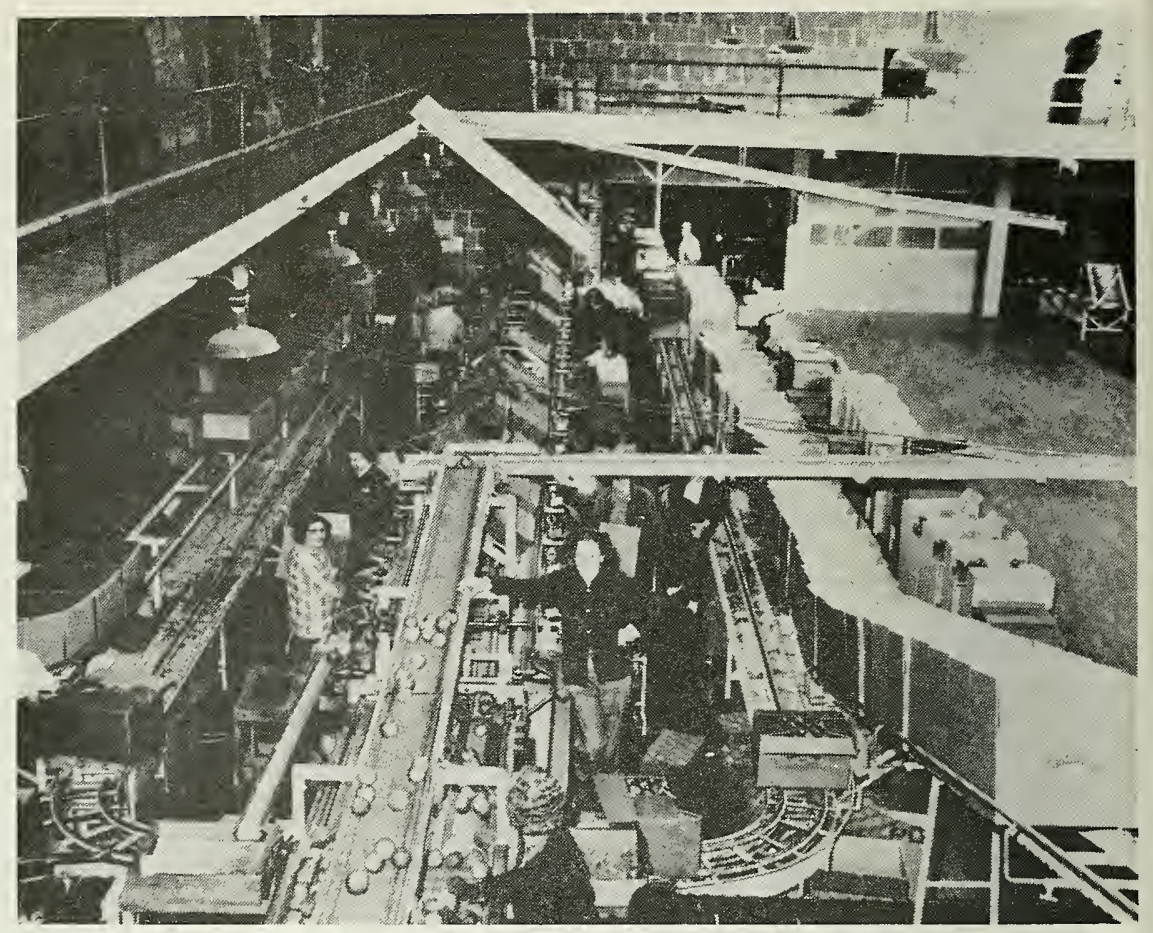

PICTURE 2a. Packing plant before remodeling.

old equipment), the same assumptions as previously used also may be used in this case. That is, the additional annual cost of owning and operating (exclusive of operating labor) the remodeled packing operation is 20 per cent of the cash outlay $(\$ 35,000)$. Therefore, the additional annual cost would be $\$ 7,000$.

Again, using a wage rate of $\$ 1.00$ per hour, a packing operation would need to pack a volume of 53,500 bushels annually before any savings would be made by remodeling. However, under the same assumptions and with a packed volume of 100,000 bushels, there would be an annual net savings of more than $\$ 6,000$ from remodeling. Through remodeling changes, relatively high-cost operators could bring about even greater reductions in labor requirements per unit.

\section{Conclusion}

Two significant points emerge from this study: (1) the opportunity for apple-packing operators to recluce their costs of packing and handling apples, and (2) the importance of volume. It should be emphasized that the two plants studied were relatively low-cost packing houses before changes were introduced. 


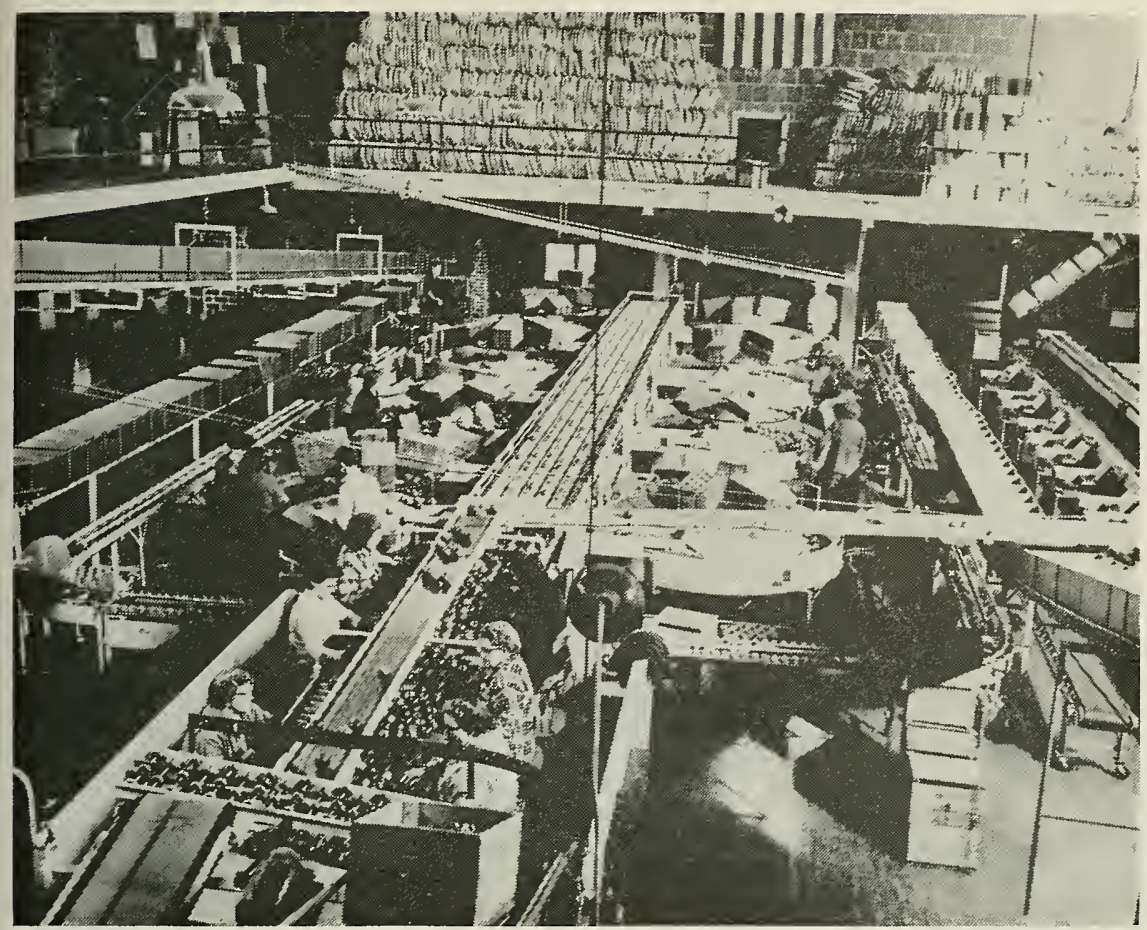

PICTURE 2b. The same plant after remodeling.

The findings of this report should encourage all apple packers to evaluate their handling and packing costs in terms of possible cost reductions. It is primarily through relative reductions in costs that one area improves its competitive position compared to other areas. The operator who adopts improved technology first, also improves his com petitive position relative to those operators that follow his example. 


